\title{
RESGATE DE MACIEIRAS ANTIGAS NO RIO GRANDE DO SUL - UMA OPÇÃO PARA A MANUTENÇÃO DA DIVERSIDADE GENÉTICA
}

\author{
ROSA MARIA VALDEBENITO SANHUEZA \& PAULO RICARDO DIAS DE OLIVEIRA \\ EMBRAPA UVA E VINHO, CP 130, CEP 95700-000, BENTO GONÇALVES-RS
}

A produção comercial de maçãs no Brasil tem ao redor de 30 anos e ocupa aproximadamente 32 mil ha na região Sul do Brasil. Nas primeiras áreas de produção, foram empregadas mais de 10 cultivares diferentes, com predominância de materiais oriundos da Europa e do Japão. A partir da década de 80 do século passado, começou a ser delineada uma concentração varietal nas novas áreas de plantio, decorrente da maior adaptação e da aceitação pelo mercado, o que levou ao plantio quase exclusivo das cultivares Gala e Fuji e suas mutações, sendo eliminadas as do grupo Delicious, entre outras.

As técnicas de manejo das cultivares foram aperfeiçoadas pela pesquisa e pelo desenvolvimento de ações em parceria com o setor produtivo, que até hoje conta com técnicos de excelente formação em fruticultura.

Nesse cenário, os programas de melhoramento conduzidos no Brasil e a introdução de novas cvs. sempre mantinham como meta final a obtenção de materiais genéticos semelhantes às características da cv. Gala e/ou Fuji, procuravam materiais com maturação no período entre as duas cvs. principais e tinham como alvo a resistência à sarna da macieira (Venturia inaequalis) utilizando fontes de resistência semelhantes aos utilizados em outros programas deste tipo no exterior.

Nesta situação, a preocupação inicial estava centrada no impacto que teria a introdução de uma doença quarentenária, numa população geneticamente homogênea de macieiras, principalmente porque, nessa época, havia importação maciça de porta-enxertos e de plantas enxertadas de diversos países.

Felizmente isto não ocorreu. Todavia, o surgimento da epidemia da mancha foliar da Gala (Colletotrichum gloeosporioides), iniciada a partir de 1990, e que causou perdas elevadas em toda a região produtora de maçãs no País, somada à constatação da quebra de resistência à sarna da macieira das cvs. que utilizavam o gene Vf na Europa, deu um alerta aos pesquisadores da Embrapa Uva e Vinho quanto à necessidade de buscar estratégias alternativas que garantissem maior variabilidade para a cultura.

Contribuíram para reforçar este tipo de preocupação a análise e o acompanhamento do sistema produtivo da maçã, iniciado a partir de 1997 por uma equipe multidisciplinar que veio discutir e pesquisar os sistemas de Produção Integrada de Maçãs (PIM) e, posteriormente, a produção orgânica de maçãs.

Nessa época, esta discussão já ocorria nos eventos de Produção Integrada de Frutas na Europa e relatavam-se os primeiros resultados dos esforços feitos para resgatar as fontes de variabilidade abandonadas ou perdidas durante o processo de melhoramento. Citavase, também, a organização de uma rede de pesquisa formada por diversos países europeus a qual tinha a função de avaliar macieiras antigas das suas regiões que tivessem potencial para serem utilizadas como cvs. regionais e/ou como fontes de germoplasma para os programas de melhoramento e para estudos de resistência durável para as duas doenças mais importantes na Europa: a sarna e o oídio da macieira.

As primeiras ações destinadas ao resgate das cvs. antigas disponíveis no Sul do Brasil foram feitas pela Embrapa Uva e Vinho em 2002, percorrendo-se propriedades rurais e pomares caseiros nas cidades do norte e nordeste do Rio Grande do Sul. Esses locais foram identificados com auxílio das informações de produtores e de agentes da Extensão Rural (Emater/RS) e neles verificava-se a sobrevivência de plantas de idade superior a 60 anos que ainda produziam mesmo sem tratamentos com agrotóxicos e que, originalmente, tinham sido trazidas pelos imigrantes europeus (Figura 1). Nessas plantas (Fig 1), avaliavase a presença de sintomas de patógenos, sendo o alvo principal a infecção por Venturia inaequalis (sarna da macieira) e por Colletotrichum gloeosporioides (Mancha foliar da Gala) .

Posteriormente, esses materiais foram enxertados, multiplicados e avaliados após inoculação artificial e natural quanto à suscetibilidade aos patógenos-alvo. Os resultados preliminares confirmaram que parte destas macieiras antigas tinham o potencial quanto à resistência aos patógenos (Fig 2).

Na continuidade destas ações de valorização da diversidade genética da macieira no Brasil, foi ajustada, em 2003, uma cooperação científica entre a Embrapa Uva e Vinho e o INRA (Institut National de la Recherche Agronomique) de Angers, França, focalizada nesta temática. Nas ações de cooperação previstas, busca-se aprofundar tal abordagem pela condução de linha de pesquisa em biologia molecular (genotipagem e detecção de genes de resistência) e em outras áreas.

Ações de resgate de diversidade genética estão sendo iniciadas com pereiras e poderão ser ampliadas para outras fruteiras temperadas que se encontrem na região Sul. Estes materiais serão importantes, tanto como fontes para adaptação regional dessas espécies, como para resistência a pragas.

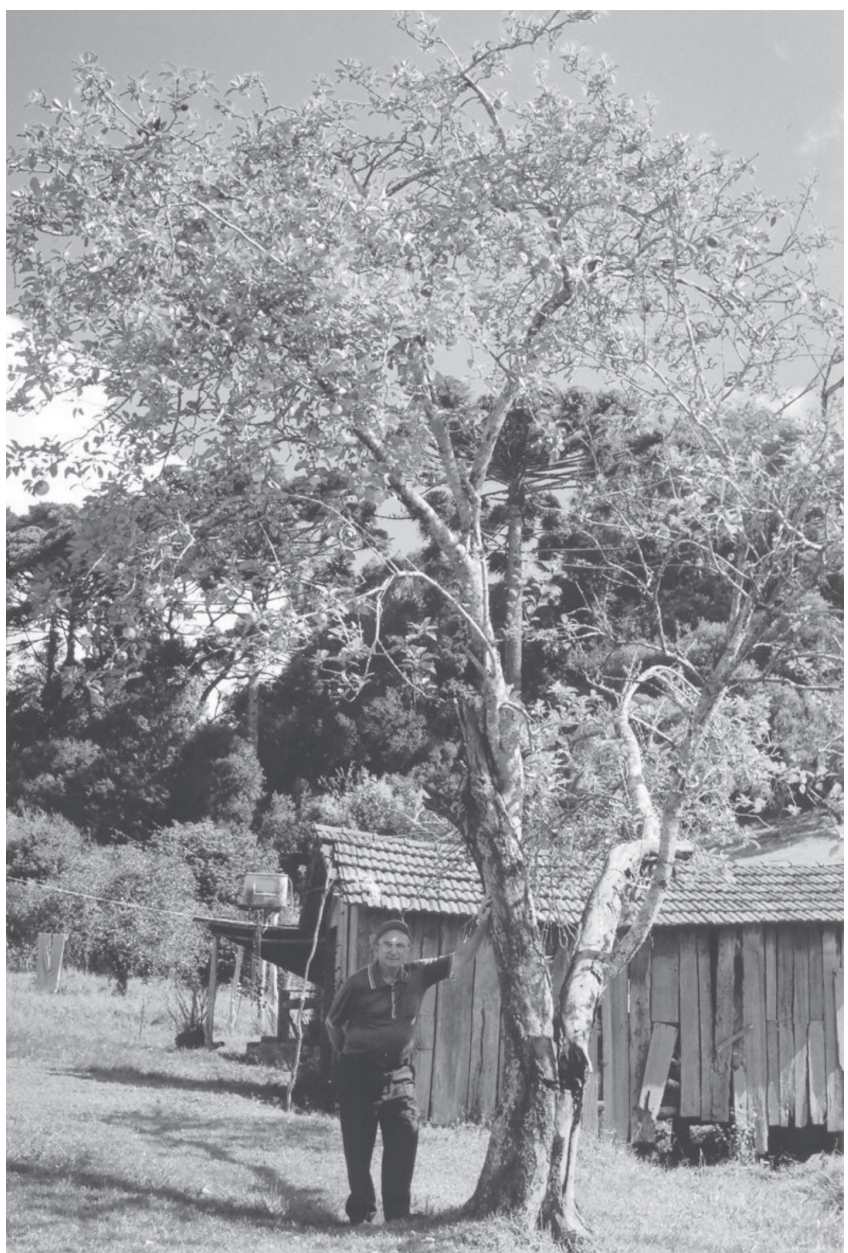

FIGURA 1 - Macieira antiga no interior do Rio Grande do Sul 


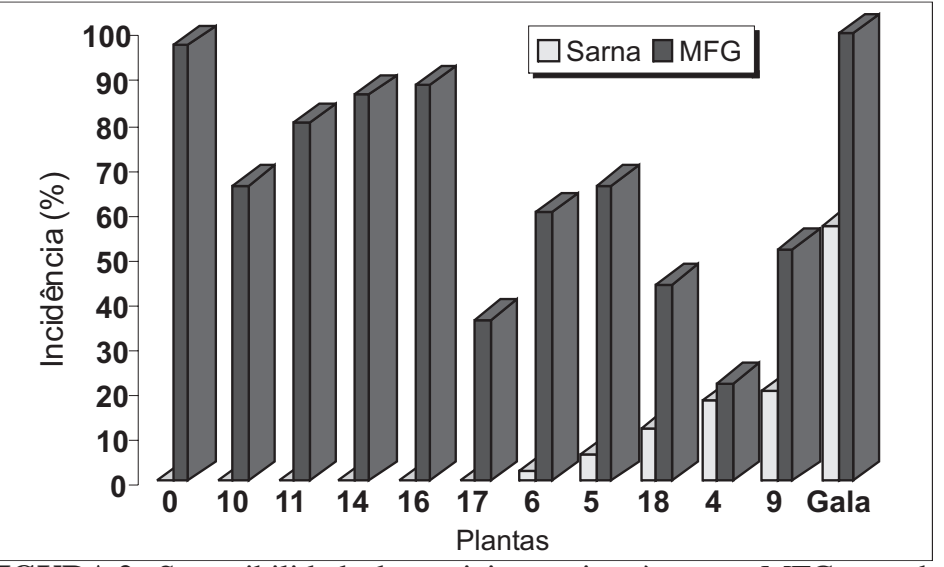

FIGURA 2 - Suscetibilidade de macieiras antigas à sarna e MFG-mancha foliar da Gala, safra 2003-2004, Vacaria-RS.

\section{LITERATURA CONSULTADA}

BÉNAOUF, G.; PARISI, L. Genetics of host-pathogen relationships between Venturia ínaequalis races 6 and 7 and Malus species.
Phytopathology, v.90, p.236-242, 2000.

BONETI, J.I.S.; RIBEIRO, P.A.; DENARDI, F.; CAMILO, AP.; BRIGHENTI, E.; PEREIRA, AJ. Epagri 402 - Catarina: nova cultivar de macieira resistente à samBo Agropecuária Catarinense, v.9, p.5154, 1996.

DUPONCHEEL, A.; PAUWELS, E.; KEULEMANS, J. Durability of scab (Venturia ínaequalis) resistance in apple and combination of different resistance sources. IOBCIWPRS Bulletin, v.23, p.277285, 2000.

KELLERHALS, M.; FURRER, B. Approaches for breeding apples with durable disease resistance. Euphytica, v.77, p.31-35, 1994.

LESPINASSE, Y.; DUREL, C.E.; PARISI, L.; LAURENS, F.N.D.; CHEVALIER, M.; PINET, C. An European project: D.ARE - Durable Apple Resistance in Europe. Durable resistance of apple to scab and powdery-mildew: one step more towards na environmental friendlyorchard. IOBCIWPRS Bulletin, v.23, p.257-260, 2000.

PARISI, L.; LESPINASSE, Y.; GUILLAUMES, J.; KRUGER, J. A new face of Venturia ínaequalis virulent to apples withresistance due to the Vf gene. Phytopathology, v.83, p.533-537, 1993. 